\title{
PENINGKATAN KEMAMPUAN MEMAHAMI TEKS TANTANGAN MENGGUNAKAN METODE PEMBELAJARAN STAD SISWA KELAS IX SMPN 1 KARANGPLOSO
}

\author{
Diah Erna Triningsih \\ SMP Negeri 1 Karangploso \\ Jalan PB. Sudirman 49 Karangploso, Malang \\ E-mail: alifahzhafira@gmail.com
}

\begin{abstract}
This study aims to see the improvement to understand challenge text of the ninenth graders of SMPN 1 Karangploso using STAD of cooperative learning method. This study used classroom action research assigning 31 students consisting of 14 male and 17 female students. This research implemented two cycles each of which applied planning, implementing, observing and reflection. The results showed that the ability to understand the text of the challenge increased in cycle 1. Distributions of students accomplishment are $10(33.33 \%)$ low, 15 (48.39\%) moderate, and 6 (19.35\%) high. In cycle 2, students accomplishment are satisfied as no low scores are achieved. Middle scores are gained by $17(54,83 \%)$ having a score range of 78-84, and 14 $(45.16 \%)$ achieved very good score ranging from 85-100. Attainment of students activities during the class has also increased from $65 \%$ to $82 \%$ showing that STAD method evidently improves students attainment on challenge text.
\end{abstract}

Keywords: STAD method, understanding, text, challenge text, attainment.

DOI:10.30957/Cendekia.v12i2.520.

\section{PENDAHULUAN}

Membaca tidak dapat dipisahkan dari pendidikan karena membaca sebagai alat yang digunakan dalam proses pendidikan dan alat untuk menyampaikan tujuan dalam pengajaran. Oka (1983:66) menjelaskan bahwa kedudukan membaca dalam pendidikan, di satu pihak sebagai integral yaitu bagian yang tak dapat dipisahkan dari keutuhan pendidikan dan di pihak lain, pengajaran membaca berkedudukan sebagai alat dan media fungsional yaitu alat dan media yang mempunyai tersendiri dalam keseluruhan pendidikan.

Salah satu kemampuan membaca yang diajarkan di SMP yaitu membaca pemahaman. Membaca pemahaman diartikan sebagai kegiatan membaca yang dilakukan untuk memahami isi bacaan secara mendalam sehingga pembaca dapat menemukan berbagai informasi yang terdapat dalam bacaan. Nurhadi (1987:53) menyebutkan bahwa membaca pemahaman adalah kemampuan yang merupakan hasil latihan, yang barangkali didukung pula faktor-faktor bawaan tertentu. Akan tetapi, 
CENDEKIA, Vol. 12. No. 2 Oktober 2018

p-ISSN: 1978-2098; e-ISSN: 2407-8557

Http://cendekia.pusatbahasa.or.id; Email: cendekiaoslo@gmail.com

Center of Language and Cultural Studies, Surakarta, Indonesia

Triningsih, Erna Diah. 2018. Peningkatan Kemampuan Memahami Teks Tantangan

Menggunakan Metode Pembelajaran STAD Siswa Kelas IX SMPN 1 Karangploso.

Cendekia (2018), 12(2): 85-98. DOI:10.30957/Cendekia.v12i2.520.

kemampuan membaca sebenarnya merupakan hasil pembiasaan dan latihan sehingga diperoleh tahap yang tinggi keefektifannya.

Kompetensi Dasar (KD) dalam Kurikulum 2013 untuk kelas IX SMP pada ranah pengetahuan menyebutkan bahwa peserta didik diharapkan dapat memahami teks eksemplum, teks tanggapan kritis, teks tantangan, dan teks rekaman percobaan baik lisan maupun tulisan. Teks tantangan merupakan teks yang tergolong baru dalam pembelajaran bahasa Indonesia. Materi pokok teks tantangan dapat dijabarkan menjadi beberapa indikator antara lain memahami struktur, memahami ciri bahasa, dan memahami isi teks tantangan. Berdasarkan indikator tersebut, ada beberapa kegiatan pembelajaran yang dapat dilakukan antara lain membaca, menentukan gagasan utama, mengidentifikasi struktur, mengidentifikasi ciri bahasa, dan menyimpulkan isi teks. Kegiatan tersebut termasuk aktivitas dalam membaca pemahaman.

Teks tantangan merupakan teks yang berisi tanggapan berupa sanggahan maupun penolakan terhadap kebijakan atau permasalahan umum yang disertai bukti dan data pendukung. Pada umumnya penggunaan teks tantangan digunakan seseorang untuk menolak, menentang, membantah, maupun menyanggah kebijakan secara santun karena disampaikan dengan benar. Teks tantangan berfungsi untuk menyampaikan pendapat meskipun berupa penolakan maupun sanggahan agar peserta didik dapat meningkatkan cara berpikir kritis membaca kebijakan dan permasalahan di masyarakat. Berpikir kritis merupakan seni untuk berpikir untuk menganalisis dan mengevaluasi pemikiran terhadap permasalahan (Paul dan Linda, 2006:4). Berpikir kritis mencakup kegiatan interogasi, menyelidiki, menganalisis, menguji dan menjelajahi informasi tertentu untuk mencapai simpulan tertentu (Scafersman, 2008:1). Oleh karena itu, berpikir kritis dapat membudidayakan sikap peserta didik dalam merumuskan pertanyaan dan masalah dengan jelas dan tepat, mengumpulkan dan menilai informasi yang relevan, menggunakan ide-ide abstrak untuk menafsirkan efektif, menyimpulkan solusi dengan alasan yang tepat, menilai sesuatu menggunakan asumsi yang benar (Suriati, dkk, 2018).

Teks tantangan memiliki tiga struktur meliputi pengantar, argumen menentang, simpulan. Pengantar, struktur pertama dalam teks tantangan berisi mengenai pernyataan umum yang disampaikan oleh penulis mengenai konflik yang ada dalam teks sekaligus isu (hal yang ditentang). Argumen menentang, bagian kedua setelah pengantar berisi pendapat, komentar, tanggapan yang menolak, membantah, menyanggah isu yang dibahas (kebijakan) yang disertai data-data atau alasan penolakan tersebut. Simpulan, struktur terakhir teks tantangan berisi hasil akhir analisis penulis terhadap penolakan tersebut. Selain berisi analisis akhir, bagian ini juga berisi saran terhadap permasalahan yang dibahas.

Teks tantangan memiliki beberapa ciri berdasarkan kalimat-kalimat yang digunakan. Ciri bahasa tersebut meliputi penggunaan kalimat penolakan dan kalimat sanggahan. Kalimat penolakan ditandai penggunaan kata tidak setuju, tidak sependapat, membantah, menolak, menentang. Sementara itu, kalimat sanggahan ditandai penggunaan kata kurang setuju, perlu ditinjau kembali, belum sesuai, sebaiknya. Kalimat-kalimat yang digunakan dalam teks tantangan merupakan kalimat kompleks, yaitu penggunaan kalimat majemuk tunggal dan kalimat majemuk bertingkat yang 
CENDEKIA, Vol. 12. No. 2 Oktober 2018

p-ISSN: 1978-2098; e-ISSN: 2407-8557

Http://cendekia.pusatbahasa.or.id; Email: cendekiaoslo@gmail.com

Center of Language and Cultural Studies, Surakarta, Indonesia

Triningsih, Erna Diah. 2018. Peningkatan Kemampuan Memahami Teks Tantangan

Menggunakan Metode Pembelajaran STAD Siswa Kelas IX SMPN 1 Karangploso.

Cendekia (2018), 12(2): 85-98. DOI:10.30957/Cendekia.v12i2.520.

ditandai penggunaan konjungsi intrakalimat dan konjungsi antarkalimat (tetapi, namun, sehingga, agar, oleh karena itu, dengan demikian dan lain-lain).

Berdasarkan observasi yang dilakukan pada 09 Oktober 2017 menunjukkan bahwa pemahaman peserta didik terhadap teks tantangan masih rendah. Hal ini dibuktikan dengan hasil pretes yang menunjukkan rata-rata kelas hanya 68,73 padahal kriteria ketuntaasan minimal (KKM) materi memahami teks tantangan adalah 75. Selain itu, peserta didik kurang antusias selama proses pembelajaran. Peserta didik belum menunjukkan keaktifan selama proses pembelajaran. Hal ini tampak ketika guru mengajukan pertanyaan, menggiring peserta didik pada penyimpulan, maupun mencoba memberikan tanggapan terhadap isi teks peserta didik justru diam hanya tujuh peserta didik yang aktif menjawab. Di pihak lain, hasil penelitian Program for International Student Assessment menemukan bahwa pada tahun 2009 Indonesia berada pada peringkat ke-57 dari 65 negara di dunia dalam hal reading literacy (dalam Sudaryanto, 2012).

Berdasarkan wawancara dengan guru bahasa Indonesia lainnya, kecenderungan kurang aktifnya peserta didik dalam pembelajaran dikarenakan peserta didik merasa jenuh. Peserta didik kurang tertantang dengan metode pembelajaran berkelompok yang monoton. Pembelajaran bahasa Indonesia di kelas IX G telah dilaksanakan secara berkelompok, tetapi aktivitas kelompok hanya didominasi satu dua peserta didik. Prosedur pembelajaran memahami teks tantangan dilakukan dengan cara pembagian kelompok, membaca teks tantangan, mengidentifikasi struktur dan ciri bahasa kemudian penilaian. Pembelajaran kooperatif sudah diterapkan, tetapi masih setengah-setengah. Pembelajaran kooperatif merupakan bentuk pembelajaran dengan cara peserta didik belajar dan bekerja dalam kelompok kecil secara kolaboratif yang anggotanya terdiri dari empat sampai enam orang dengan struktur kelompok yang bersifat heterogen (Rusman, 2010:202). Oleh karena itu, perlu penggunaan metode pembelajaran yang menarik dan menantang peserta didik agar aktif dalam proses pembelajaran.

Pada pelaksanaan pembelajaran memahami teks tantangan, peneliti menggunakan metode pembelajaran Student Teams Achievement Division (STAD). Dengan metode STAD ini memungkinkan peserta didik belajar tidak hanya sekedar mengingat maupun menghafal, tetapi aktif berinteraksi dengan peserta didik lain sehingga proses belajar di dalam kelas akan lebih jelas terlihat bagaimana terjadi perubahan pengetahuan, pemahaman, tingkah laku, keterampilan, daya respon dan reaksinya dalam sebuah kelompok belajar (Handayani, 2017). Selain itu, penggunaan metode STAD dapat melatih pula kemampuan individual peserta didik.

Selain permasalahan tersebut, peneliti juga mengacu pada hasil beberapa penelitian tentang penggunaan metode pembelajaran kooperatif tipe STAD. Penelitian Mulyanto (2011) menyimpulkan bahwa metode STAD dapat meningkatkan kuallitas pembelajaran menulis karangan pada peserta didik kelas III SD Negeri 3 Ngargosari, Boyolali. Peningkatan tersebut terlihat pada hasil belajar peserta didik pratindakan terdapat 57,14\% peserta didik yang belum tuntas, setelah tindakan siklus 2 terdapat $92,85 \%$ peserta didik yang telah mencapai nilai lebih dari kriteria ketuntasan minimal (KKM) yang ditetapkan, yaitu 65 . 
Penelitian Marcelina (2012) menyimpulkan bahwa penerapan metode STAD dalam pembelajaran menulis surat dinas efektif dilakukan di kelas VIII SMPN 4 Bandung. Hal ini berdasarkan hasil tes sebelum perlakuan diperoleh skor rata-rata 56 dan setelah perlakukan hasil yang diperoleh 76 pada kelas eksperimen. Hasil menunjukkan perbedaan yang signifikan antara kemampuan siswa dalam menulis surat dinas sebelum dan sesudah diberi perlakuan dengan menggunakan metode STAD pada siswa kelas VIII SMPN 4 Bandung tahun ajaran 2012/2013.

Penelitian Kumarawati, dkk (2015) menyimpulkan bahwa penerapan metode pembelajaran kooperatif tipe STAD dapat meningkatkan kemampuan menulis teks laporan hasil observasi peserta didik kelas X MIA 1 SMAN 1 Mendoyo. Selain peningkatan hasil belajar, peserta didik juga memberikan tanggapan positif terhadap metode pembelajaran STAD dalam menulis teks laporan hasil observasi.

Berdasarkan uraian di atas, peneliti melakukan penelitian berjudul "Peningkatan Kemampuan Memahami Teks Tantangan dengan Metode Pembelajaran STAD untuk Peserta didik Kelas IX SMP N 1 Karangploso".

\section{METODE}

\subsection{Jenis Penelitian}

Jenis penelitian merupakan Penelitian Tindakan Kelas (PTK). Penelitian tindakan adalah penelitian yang dilakukan oleh guru di dalam kelasnya sendiri melalui refleksi diri, dengan tujuan untuk memperbaiki kinerjanya sebagai guru, sehingga hasil belajar peserta didik menjadi meningkat (Mulyasa, 2009). Penelitian dilaksanakan di SMP Negeri 1 Karangploso yang beralamat di Jl. PB. Sudirman 49 Karangploso, Kabupaten Malang. Penelitian ini dilaksanakan pada peserta didik kelas IX-C SMPN 1 Karangploso, Malang.

Penelitian diawali dengan observasi pada tanggal 09 Oktober 2017. Pelaksanaan dimulai tanggal 25 Oktober 2017 berdasarkan perencanaan dan hasil pengamatan dan penilaian hasil pretes memahami teks tantangan. Penelitian dilaksanakan dalam dua siklus. Pembelajaran memahami teks tantangan dengan metode pembelajaran STAD Siklus 1 dilaksanakan sebanyak satu kali pertemuan pada tanggal 25 Oktober 2017. Pembelajaran memahami teks tantangan dengan metode pembelajaran STAD Siklus 2 dilaksanakan sebanyak satu kali pertemuan pada tanggal 30 Oktober 2017 materi memahami teks tantangan.

\subsection{Prosedur Penelitian}

Subjek penelitian yaitu peserta didik kelas IX-C SMPN 1 Karangploso tahun pelajaran 2017/2018 sebanyak 31 peserta didik yang terdiri dari 14 peserta didik dan 17 siswi. Pemilihan kelas IX-C sebagai subyek penelitian didasarkan nilai KKM pada pembelajaran memahami teks tantangan tergolong rendah dibanding kelas lain. Peserta didik kelas IX-C SMPN 1 Karangploso, Kabupaten Malang yang dijadikan subjek penelitian memiliki kemampuan yang heterogen. Pemilihan terhadap subjek penelitian yang heterogen dimaksudkan agar tidak ada perbedaan kemampuan antar peserta didik. Hal ini bertujuan untuk menciptakan kondisi pembelajaran yang alamiah. 
Menurut Arikunto (2010) data adalah hasil pencatatan peneliti, baik berupa fakta maupun angka. Data dibutuhkan untuk mendapatkan informasi atau jawaban penelitian. Pada penelitian ini, data diperoleh dari proses pembelajaran memahami teks tantangan menggunakan metode pembelajaran STAD dan diperoleh hasil menjawab kuis berdasarkan isi teks.

Data proses diperoleh dari (1) hasil observasi terhadap pelaksanaan proses pembelajaran memahami teks tantangan, (3) data hasil angket mengenai tanggapan peserta didik terhadap proses pembelajaran memahami teks tantangan baik sebelum maupun setelah menggunakan metode pembelajaran STAD. Sementara itu, data hasil belajar peserta didik yang bersumber dari rubrik penilaian terhadap hasil jawaban peserta didik dalam menjawab kuis. Sementara itu, sumber data dalam penelitian ini adalah peserta didik dan guru. Sebagai sumber data utama dalam penelitian ini adalah peserta didik kelas IX-C yang melaksanakan pembelajaran memahami teks tantangan. Sumber data guru untuk mengetahui hasil kemampuan awal memahami teks tantangan, proses tindakan pembelajaran memahami teks tantangan dengan menggunakan metode pembelajaran STAD.

Penelitian tidakan kelas ini berlangsung mulai Oktober hingga Desember 2017. Teknik pengumpulan data melalui (1) observasi terhadap aktivitas guru dan peserta didik selama pembelajaran berlangsung untuk mengetahui keterlaksanaan metode pembelajaran STAD dengan menggunakan lembar observasi; (2) angket dengan menggunakan panduan angket untuk peserta didik pada studi pendahuluan dan setelah proses tindakan berlangsung, untuk mengetahui permasalahan peserta didik serta pendapat peserta didik setelah melaksanakan pembelajaran.

Data hasil dikumpulkan dari jawaban peserta didik pada tahap studi pendahuluan, siklus 1, dan siklus selanjutnya. Data hasil ini dikumpulkan dari rubrik penilaian yang telah dibuat oleh peneliti. Skor yang diperoleh disajikan dalam bentuk tabel yang menunjukkan skor peserta didik dari tes studi pendahuluan dan skor peserta didik setelah memperoleh tindakan. Data hasil digunakan untuk mengetahui meningkat atau tidaknya kemampuan peserta didik dalam pembelajaran memahami teks tantangan menggunakan metode pembelajaran STAD. Adapun instrumen dalam penelitian ini yang digunakan berdasarkan teknik pengumpulan data di atas adalah panduan observasi pembelajaran, panduan angket, dan lembar tes tulis. Panduan observasi disusun berdasarkan fokus penelitian serta kriteria yang diamati selama proses pembelajaran pada peserta didik. Panduan angket berisi pertanyaan atau pernyataan peserta didik terkait pembelajaran memahami teks tantangan pada tahap studi pendahuluan hingga akhir tindakan. Terakhir, lembar tes digunakan untuk mengetahui tingkat keberhasilan tindakan berdasarkan alat ukur yang telah dibuat oleh peneliti.

\subsection{Pelaksanan Tindakan \\ 1. Perencanaan}

Pada tahap perencanaan peneliti menyiapkan segala sesuatu yang dibutuhkan saat penelitian, yaitu (1) menyusun Rencana Pelaksanaan Pembelajaran (RPP), (2) membuat materi pembelajaran teks tantangan yang digunakan saat pelaksanaan proses pembelajaran, (3) membuat soal yang akan dikerjakan dan didiskusikan oleh siswa serta 
mengonsultasikan kepada kolaborator, guru bahasa Indonesia, (4) membuat panduan observasi berupa lembar observasi untuk mencatat kejadian selama proses pembelajaran, dan (5) menyiapkan angket untuk mengetahui respon siswa terhadap proses pembelajaran.

\section{Pelaksanaan}

Tindakan yang dilakukan di dalam kelas disesuaikan dengan rencana pembelajaran yang telah disiapkan dalam RPP. Hal-hal yang dilakukan pada tahap ini adalah:

\section{a. Pendahuluan}

Pada tahap ini dilakukan beberapa hal berkaitan dengan proses pelaksanaan pembelajaran memahami teks tantangan dengan model pembelajaran STAD. Kegiatan pendahuluan meliputi a) Peserta didik berdoa, b) guru mengondisikan siswa dan mempresensi kehadiran siswa, c) guru menyampaikan tujuan pembelajaran yang hendak dicapai dalam kegiatan pembelajaran.

\section{b. Kegiatan Inti}

Kegiatan Inti meliputi lima tahap. Presentasi Kelas, pendidik menyajikan materi pelajaran secara garis besar. Pada tahap ini penyajian dapat berupa ceramah dan presentasi menggunakan audiovisual. Peneliti menggunakan teks tantangan berjudul Larangan Membawa Sepeda Motor bagi Siswa SMP. Tahap Belajar Kelompok, kelompok berdiskusi setelah peneliti menjelaskan materi pokok. Peserta didik mendiskusikan beberapa pertanyaan untuk mengidentifikasi isi teks. Tahap Kuis, setelah satu atau dua kali peneliti menyampaikan materi dan dilakukan diskusi kelompok, kemudian diadakan kuis secara individual. Kuis ini berupa pilihan ganda dan uraian. Tahap Peningkatan Skor Individu, pendidik menentukan peningkatan skor individu dan skor kelompok. Setiap peserta didik akan diberikan skor "awal", kemudian akan dibandingakan dengan skor hasil kuis mereka. Tahap Penghargaan Kelompok, sebuah kelompok akan memperoleh suatu penghargaan jika skor rata-rata kelompok tersebut sesuai dengan kriteria.

\section{c. Penutup}

Pada kegiatan penutup, guru melakukan refleksi pembelajaran, menyimpulkan hasil diskusi kelas, menyampaikan materi yang akan dipelajari pada pertemuan selanjutnya, memimpin doa dan menutup dengan salam.

\section{Pengamatan}

Kegiatan pengamatan dilakukan selama proses pembelajaran berlangsung. Peneliti dan kolaborator mengamati dan mencatat hasil pada lembar observasi dan catatan lapangan. Pengamatan dilakukan dengan melihat berbagai tindakan yang muncul selama pembelajaran. 


\section{Refleksi}

Refleksi dilakukan berdasarkan hasil tindakan dari siklus pertama yang tercatat dalam lembar observasi, angket, dan catatan lapangan. Berdasarkan hasil refleksi, peneliti bersama kolaborator menyusun rencana pemecahan masalah untuk memperbaiki proses pembelajaran pada siklus kedua.

\subsection{Teknik Analisia Data}

Analisis data pada penelitian tindakan kelas dilakukan sebelum memasuki lapangan, selama di lapangan, dan setelah selesai di lapangan. Analisis data sebelum memasuki lapangan dilakukan terhadap data hasil studi pendahuluan, atau data sekunder. Analisis data selama dan setelah di lapangan meliputi pengumpulan data, reduksi data dan penyajian data (Tampubolon, 2014:33). berikut.

Hasil analisis data hasil memahami teks tantangan dinilai dengan rumus sebagai

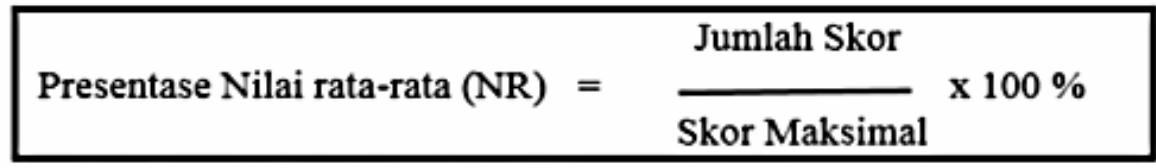

Sumber: Arikunto (2010: 272)

Nilai standar Kriteria Ketuntasan Minimal (KKM) dalam penelitian ini yaitu $\geq$ 75. Hal ini berdasarkan KKM Bahasa Indonesia yang ditetapkan di sekolah. Peserta didik dikatakan tuntas belajar apabila mendapatkan skor 75 , sedangkan yang mendapat skor kurang dari 75 dianggap belum tuntas.

Indikator keberhasilan penelitian ini dilihat berdasarkan nilai proses dan hasil memahami teks tantangan. Berdasarkan proses memahami teks tantangan diperoleh data keterlaksanan pembelajaran. Jika hasil analisis pengamatan keterlaksanaan pembelajaran dapat mencapai proses presentase rata-rata $\geq 80 \%$, maka proses pembelajaran terlaksana dengan baik. Hal tersebut seperti tergambar dalam tabel 1 .

Tabel 1 Tabel Kriteria Keterlaksanaan Proses Pembelajaran

\begin{tabular}{ccc}
\hline No & Nilai rata-rata (\%) & Kriteria \\
\hline 1 & $81-100$ & Sangat Tinggi \\
2 & $61-80$ & Tinggi \\
3 & $41-60$ & Sedang \\
4 & $21-40$ & Rendah \\
5 & $00-20$ & Sangat Rendah \\
\hline
\end{tabular}

Sumber: Ridwan dan Akdon (2009: 17-18)

Indikator keberhasilan penelitian ini berdasarkan hasil memahami teks tantangan disesuaikan KKM bidang studi Bahasa Indonesia di kelas IX SMPN 1 Karangploso Malang adalah 75. Peserta didik dikatakan tuntas belajar bila mendapat nilai $\geq 75$. 
Tingkat penguasaan peserta didik terhadap kompetensi dasar secara klasikal atau daya serap kelas dikatakan baik apabila $\geq 80 \%$ peserta didik dapat mencapai KKM.

Ketuntasan Belajar Klasikal $=\frac{\text { Jumlah siswa yang memperoleh skor } \geq 78}{\text { Jumlah seluruh siswa }} \times 100 \%$

Penelitian Tindakan Kelas ini dilaksanakan beberapa tahap, yaitu (1) studi pendahuluan, (2) perencanaan tindakan, (3) pelaksanaan tindakan, (4) pengamatan, dan (5) refleksi. Berikut alur Pelaksanaan Tindakan Kelas (PTK). Alur tindakan menggunakan alur PTK Kemmis dan Taggart (Arikunto, 2008:16).

Gambar 1 Bagan Alur Pelaksanaan Tindakan Kelas

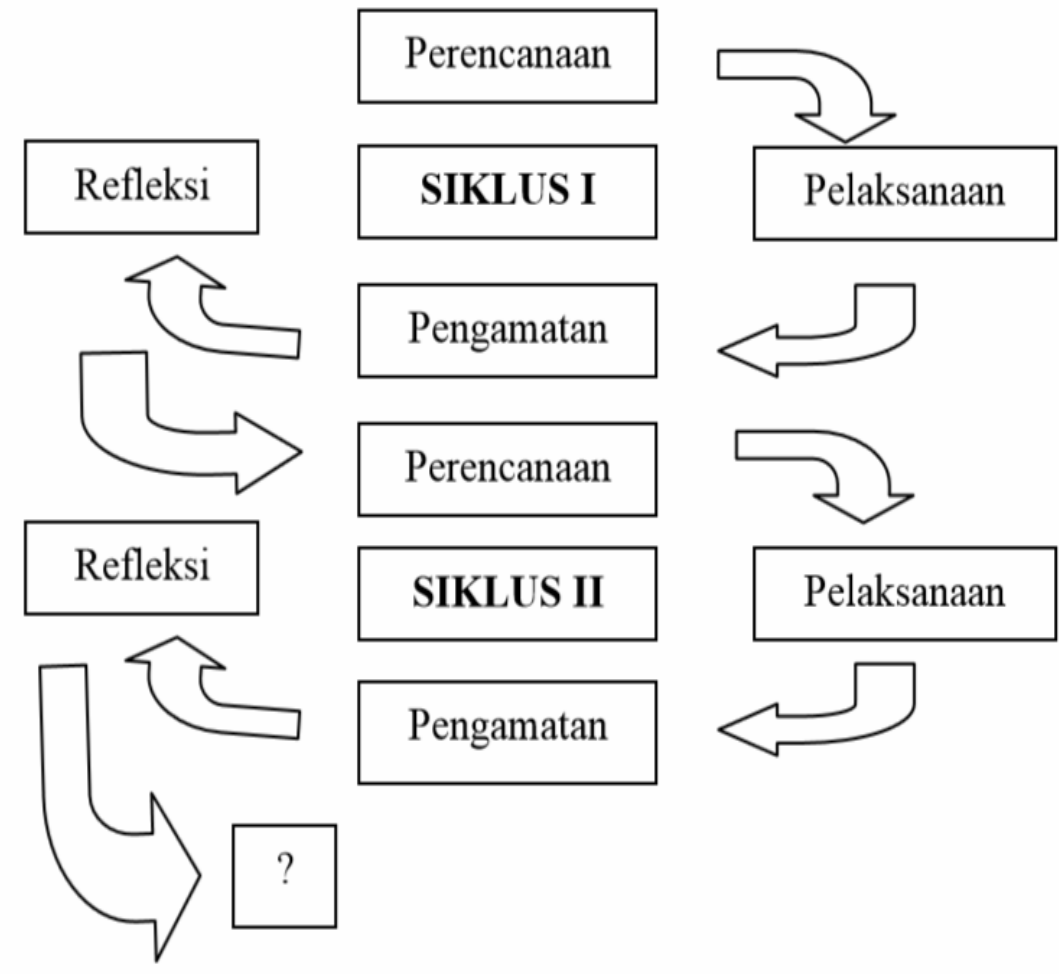

\section{HASIL DAN BAHASAN}

\subsection{Peningkatan Kualitas Proses Pembelajaran Memahami Teks Tantangan}

Peneliti melakukan studi pendahuluan mengenai pembelajaran memahami teks tantangan. Observasi dilaksanakan tanggal 09 Oktober 2017 pada 31 peserta didik kelas IX C tahun pelajaran 2017/2018 di SMP Negeri 1 Karangploso. Berdasarkan observasi awal, pembelajaran memahami teks tantangan kurang menarik bagi peserta didik karena materi pada buku teks kurang diminati peserta didik. Hal ini terlihat pada keterlibatan peserta didik dalam diskusi kelompok maupun presentasi kelas. Selain itu, pengalaman 
dari guru kolaborator menyebutkan bahwa pelaksanaan pembelajaran bahasa Indonesia belum pernah menggunakan metode pembelajaran STAD untuk materi teks tantangan.

Proses pembelajaran memahami teks tantangan dilakukan dengan menjawab soal pada buku teks secara tertulis dan dikerjakan secara kelompok. Kelompok dibuat sendiri oleh peserta didik berdasarkan kedekatan, bukan faktor peringkat. Selain itu, proses penilaian dilakukan guru tanpa melibatkan murid karena guru menuliskan jawaban dan peserta didik mencocokkan jawaban guru dengan jawaban peserta didik. Dengan pembelajaran yang kurang menarik dan kurang menyenangkan, hasil belajar peserta didik kurang memuaskan. Berikut hasil observasi proses memahami teks tantangan dengan metode pembelajaran STAD yang dilakukan kolaborator. Perhatikan table hasil observasi selama proses pembelajaran memahami teks tantangan menggunakan metode STAD pada siklus 1 dan siklus 2. Periksa Tabel 2.

Tabel 2 Hasil Observasi Proses Memahami Teks Tantangan siklus 1 dan siklus 2

\begin{tabular}{llccccc}
\hline & \multicolumn{1}{c}{ Aspek Pengamatan } & $\begin{array}{c}\text { Siklus 1 } \\
\text { Jml } \\
\text { Peserta } \\
\text { No. }\end{array}$ & \% & $\begin{array}{c}\text { Siklus 2 } \\
\text { Jml } \\
\text { Peserta } \\
\text { didik }\end{array}$ & \% \\
\hline 1. & $\begin{array}{l}\text { Keseriusan peserta didik dalam } \\
\text { memahami struktur, ciri bahasa, dan } \\
\text { menyimpulkan isi teks }\end{array}$ & 22 & 73,33 & 24 & 80 \\
\hline 2. & $\begin{array}{l}\text { Ketertiban peserta didik dalam } \\
\text { mengikuti kegiatan pembelajaran }\end{array}$ & 20 & 66,67 & 23 & 76,67 \\
\hline 3. & $\begin{array}{l}\text { Kemampuan peserta didik bekerja } \\
\text { sama dalam belajar kelompok }\end{array}$ & 21 & 70 & 25 & 83,33 \\
\hline 4. & $\begin{array}{l}\text { Kemandirian peserta didik dalam } \\
\text { menjawab kuis }\end{array}$ & 24 & 80 & 26 & 86,67 \\
\hline 5. & $\begin{array}{l}\text { Keaktifan dan kemampuan peserta } \\
\text { didik dalam memahami materi pada } \\
\text { tahap presentasi kelas }\end{array}$ & 19 & 63,33 & 23 & 76,67 \\
\hline & Rata-rata & & 70,67 & & 80,67 \\
\hline
\end{tabular}

Berdasarkan data pada tabel diketahui rata-rata peningkatan proses pembelajaran menulis makalah siklus 1 ke siklus 2 sebesar $10 \%$ yaitu dari rata-rata siklus 1 sebesar $70,67 \%$ menjadi $80,67 \%$ di siklus 2 . Rincian peningkatan hasil observasi aktivitas peserta didik dari siklus 1 ke siklus 2 berdasar data tabel sebagai berikut, keseriusan peserta didik dalam memahami struktur, ciri bahasa, dan menyimpulkan isi dari teks tantangan sejumlah 22 peserta didik pada siklus 1 dan meningkat menjadi 24 peserta didik pada siklus 2, ketertiban peserta didik dalam mengikuti kegiatan pembelajaran pada siklus 1 sebanyak 20 peserta didik dan meningkat menjadi 23 peserta didik pada siklus 2, kemampuan peserta didik dalam bekerja sama dalam kelompok pada siklus 1 sebanyak 21 peserta didik pada siklus 2 meningkat menjadi 25 peserta didik, keseriusan peserta didik dalam memecahkan masalah, kemandirian peserta didik dalam menjawab kuis sebanyak 24 peserta didik dan meningkat menjadi 26 pada siklus 2, kemampuan dan keaktifan peserta didik 
memahami materi pada tahap presentasi kelas pada siklus I sebanyak 19 peserta didik dan meningkat menjadi 23 pada siklus 2.

Metode pembelajaran STAD berhasil meningkatkan kemampuan peserta didik dalam memahami teks tantangan. Peningkatan tersebut didorong adanya keaktifan peserta didik dalam proses pembelajaran karena bukan nilai kelompok yang diperhitungkan, tetapi ada penilaian individu berdasarkan kuis. Menurut Slavin (dalam Rusman, 2011:214) gagasan utama di belakang STAD adalah memacu peserta didik agar saling mendorong dan membantu satu sama lain untuk menguasai konsep atau materi yang diajarkan. Jika peserta didik menginginkan kelompok mereka memperoleh hadiah, mereka harus membantu teman sekelompok mereka dalam mempelajari materi.

Keberhasilan belajar tidak hanya ditentukan oleh peningkatan hasil (angka), tetapi proses pembelajaran secara imbang mengalami peningkatan. Belajar adalah suatu proses yang dilakukan individu dalam menjalani perubahan tingkah laku, perkembangan juga dihayati dan dialami secara individu pula (Sugiono, 2010:15). Proses pembelajaran meningkat didasarkan pada aktivitas peserta didik selama pembelajaran berlangsung. Hal inilah yang merupakan ciri utama pembelajaran kooperatif yang bertujuan mengelompokkan peserta didik agar peserta didik dapat bekerja sama dengan kemampuan secara maksimal yang mereka miliki dan mempelajari satu sama lain dalam kelompok tersebut (Isjoni, 2010:15).

Hasil observasi tersebut juga diperkuat dengan data hasil angket yang disebar pada peserta didik setelah melaksanakan pembelajaran memahami teks tantangan menggunakan metode pembelajaran STAD. Berdasarkan hasil angket peserta didik bahwa rata-rata 23 peserta didik atau 76,67\% menyatakan bahwa peserta didik senang dan merasa mudah memahami teks tantangan dengan menggunakan metode pembelajaran STAD.

Berdasarkan kondisi riil dan temuan penelitian pada pra siklus, siklus 1, dan siklus 2 dapat dijelaskan sebagai berikut.

a. Dalam proses pembelajaran guru selalu membangun interaksi timbal balik sehingga peserta didik termotivasi untuk aktif dan bersemangat dalam mengikuti pembelajaran.

b. Guru memberikan kesempatan kepada peserta didik untuk melakukan diskusi dan tanya jawab terhadap kendala selama proses pembelajaran.

c. Guru mengupayakan terciptanya iklim belajar yang menyenangkan, tetapi tetap terarah dan dapat mencapai kompetensi dasar.

Sementara itu, partisipasi peserta didik selama proses pembelajaran dapat dijabarkan sebagai berikut.

a. Peserta didik menunjukkan kesiapan mengikuti proses pembelajaran.

b. Perhatian peserta didik terhadap materi pembelajaran cukup baik.

c. Peserta didik tertarik dengan mekanisme kerja kelompok menggunakan metode STAD karena nilai individu tetap diperhitungkan.

\subsection{Peningkatan Kualitas Hasil Memahami Teks Tantangan}

Hasil pembelajaran memahami teks tantangan menggunakan metode pembelajaran STAD meningkat. Hal ini ditunjukkan pada hasil kuis pada siklus 1 dan 
CENDEKIA, Vol. 12. No. 2 Oktober 2018

p-ISSN: 1978-2098; e-ISSN: 2407-8557

Http://cendekia.pusatbahasa.or.id; Email: cendekiaoslo@gmail.com

Center of Language and Cultural Studies, Surakarta, Indonesia

Triningsih, Erna Diah. 2018. Peningkatan Kemampuan Memahami Teks Tantangan

Menggunakan Metode Pembelajaran STAD Siswa Kelas IX SMPN 1 Karangploso.

Cendekia (2018), 12(2): 85-98. DOI:10.30957/Cendekia.v12i2.520.

siklus 2. Data peningkatan hasil belajar peserta didik dalam menulis makalah tampak seperti pada tabel 3 .

Tabel 3 Peningkatan Hasil Belajar Peserta didik Pra Siklus, Siklus 1, Siklus 2

\begin{tabular}{|c|c|c|c|c|c|c|c|c|}
\hline \multirow[b]{2}{*}{ No. } & \multirow[b]{2}{*}{ Kategori } & \multirow[b]{2}{*}{$\begin{array}{c}\text { Rentang } \\
\text { Nilai }\end{array}$} & \multicolumn{2}{|c|}{ Pra Siklus } & \multicolumn{2}{|c|}{ Siklus 1} & \multicolumn{2}{|c|}{ Siklus 2} \\
\hline & & & $\begin{array}{c}\text { Jml } \\
\text { Peserta } \\
\text { didik }\end{array}$ & $\%$ & $\begin{array}{c}\text { Jml } \\
\text { Peserta } \\
\text { didik }\end{array}$ & $\%$ & $\begin{array}{c}\text { Jml } \\
\text { Peserta } \\
\text { didik }\end{array}$ & $\%$ \\
\hline 1. & $\begin{array}{l}\text { Kelompok } \\
\text { Atas }\end{array}$ & $85-100$ & - & - & 5 & 16,67 & 11 & 36,67 \\
\hline 2. & $\begin{array}{l}\text { Kelompok } \\
\text { menengah }\end{array}$ & $75-84$ & 8 & 26,67 & 15 & 50,00 & 17 & 56,67 \\
\hline 3. & $\begin{array}{l}\text { Kelompok } \\
\text { bawah }\end{array}$ & $0-74$ & 22 & 73,33 & 10 & 33,33 & 2 & 6,66 \\
\hline & Jumlah & & 30 & 100 & 30 & 100 & 30 & 100 \\
\hline
\end{tabular}

Berdasarkan data pada tabel, diketahui bahwa sebelum mendapatkan tindakan metode pembelajaran STAD, jumlah peserta didik yang nilainya di bawah KKM atau termasuk dalam kategori kelompok bawah sebanyak 22 peserta didik atau 73,33\% dan yang termasuk dalam kategori kelompok menengah hanya 8 peserta didik atau 26,67\%. Tidak ada satu orang peserta didik yang termasuk dalam kategori kelompok atas.

Setelah mendapatkan tindakan metode pembelajaran STAD pada siklus 1, kemampuan peserta didik meningkat, yaitu jumlah peserta didik yang nilainya di bawah KKM atau termasuk dalam kategori kelompok bawah sebanyak 10 peserta didik atau $33,33 \%$ dan yang termasuk dalam kategori kelompok menengah sejumlah 15 peserta didik atau 50\%, sedangkan 5 peserta didik atau 16,67\% termasuk dalam kategori kelompok atas yaitu mendapatkan nilai 85 ke atas. Pada siklus 2, kemampuan peserta didik semakin meningkat hingga hanya ada dua peserta didik yang nilainya kurang dari KKM atau 6,66\%, sebanyak 17 peserta didik atau 56,67\% mendapatkan rentang nilai 78-84, dan sejumlah 11 peserta didik atau 36,67\% termasuk dalam kategori kelompok atas karena memperoleh nilai 85-100. Penentuan kelompok pun diatur sesuai dengan peringkat agar tiap kelompok memiliki kesetaraan kemampuan. Sebagaimana pendapat Slavin (1990) bahwa peringkat para peserta didik dalam kemampuan akademik dibuat terlebih dahulu. Masing-masing kelompok akan terdiri atas seorang peserta didik dan kelompok atas, seorang peserta didik dan kelompok bawah, dan dua orang peserta didik dengan kemampuan rata-rata. Pembentukan kelompok dengan cara semacam ini bertujuan agar diperoleh kesetaraan di antara kelompok-kelompok tersebut.

Peningkatan kemampuan peserta didik memahami teks tantangan terlihat dari kemampuan peserta didik dalam mengidentifikasi struktur teks, mengidentifikasi ciri bahasa, menentukan ide pokok, dan menyimpulkan isi teks. Adapun rincian kemampuan peserta didik tersebut terlihat pada grafik berikut. 
CENDEKIA, Vol. 12. No. 2 Oktober 2018

p-ISSN: 1978-2098; e-ISSN: 2407-8557

Http://cendekia.pusatbahasa.or.id; Email: cendekiaoslo@gmail.com

Center of Language and Cultural Studies, Surakarta, Indonesia

Triningsih, Erna Diah. 2018. Peningkatan Kemampuan Memahami Teks Tantangan

Menggunakan Metode Pembelajaran STAD Siswa Kelas IX SMPN 1 Karangploso.

Cendekia (2018), 12(2): 85-98. DOI:10.30957/Cendekia.v12i2.520.

Grafik 1 Peningkatan Kemampuan Memahami Teks Tantangan

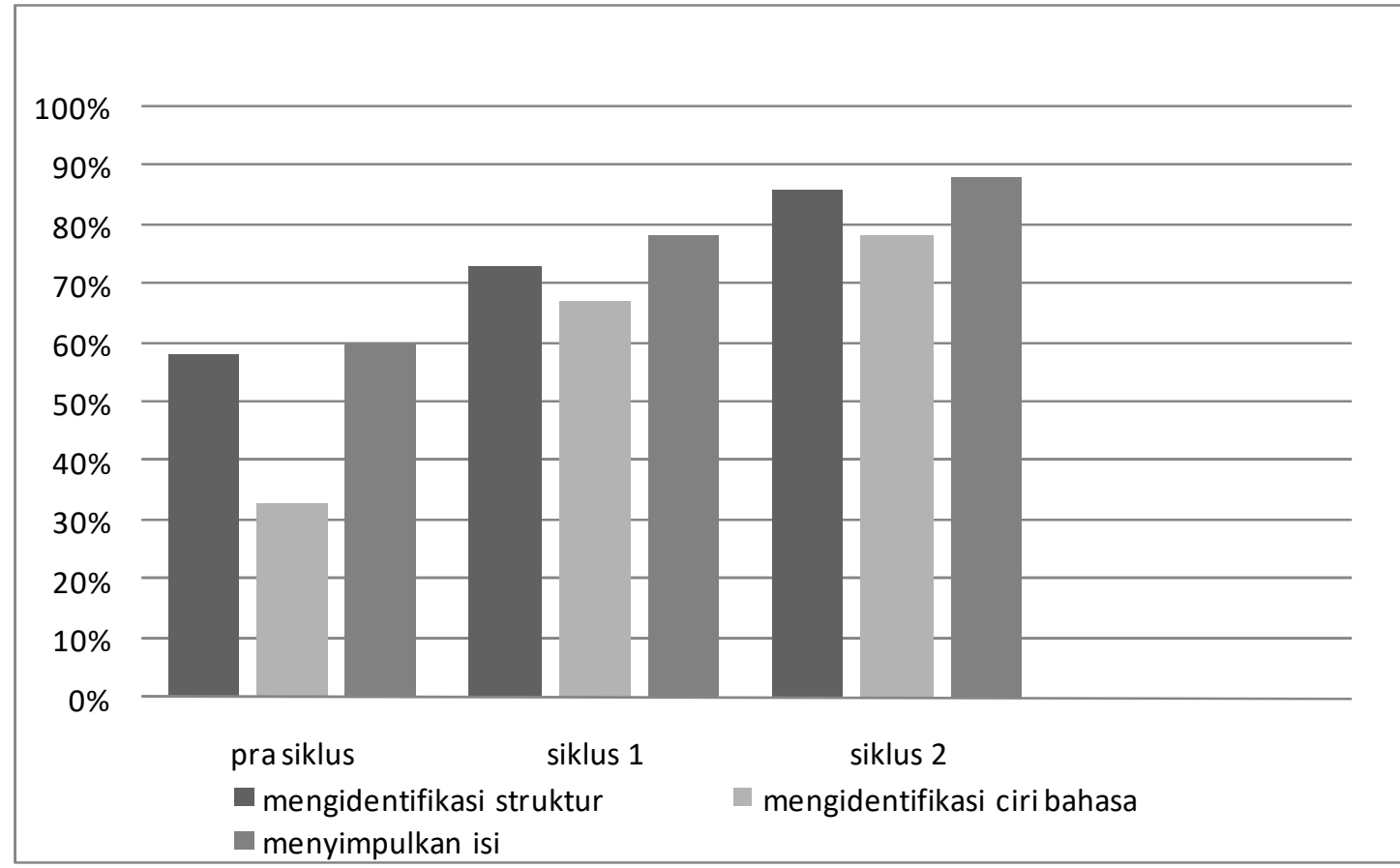

Grafik 1 menjelaskan bahwa kemampuan peserta didik mengidentifikasi struktur teks tantangan terus meningkat mulai pra siklus sebesar $58 \%$, siklus 1 meningkat menjadi $73 \%$, dan siklus 2 mencapai $86 \%$. Kemampuan peserta didik mengidentifikasi ciri bahasa meningkat meskipun di antara ketiga indikator pencapaian kompetensi memahami teks tantangan paling rendah. Pada prasiklus 33\%, sedangkan pada siklus 1 naik menjadi $67 \%$, dan pada siklus 2 telah memenuhi kriteria ketuntasan kelas dengan $78 \%$. Kemampuan peserta didik menyimpulkan isi teks pada pra siklus $60 \%$, sedangkan siklus 1 meningkat $78 \%$, dan siklus 2 mencapai 88\%. Sebagaimana pendapat Slavin (2010:143) bahwa meski para peserta didik belajar bersama, mereka tidak boleh saling membantu dalam mengerjakan kuis. Skor tim didasarkan pada kemajuan yang dibuat anggotanya dibandingkan hasil yang dicapai sebelumnya, semua peserta didik mempunyai kesempatan yang sama untuk manjadi bintang tim dalam minggu tersebut, baik dengan memperoleh skor yang lebih tinggi dari rekor mereka sebelumnya maupun dengan membuat jawaban kuis yang sempurna, yang selalu akan memberikan skor maksimum tanpa menghiraukan rata-rata skor terakhir peserta didik.

\section{SIMPULAN DAN SARAN}

Berdasarkan hasil penelitian dan pembahasan disimpulkan bahwa penerapan metode pembelajaran STAD dapat meningkatkan kemampuan memahami teks tantangan peserta didik kelas IX SMP Negeri 1 Karangploso tahun ajaran 2016/2017 yang dibuktikan dengan adanya peningkatan prosentase skor motivasi belajar dan hasil belajar pada tiap siklusnya. Berdasarkan data, diketahui bahwa sebelum mendapatkan tindakan metode pembelajaran STAD, jumlah peserta didik yang nilainya di bawah 
CENDEKIA, Vol. 12. No. 2 Oktober 2018

p-ISSN: 1978-2098; e-ISSN: 2407-8557

Http://cendekia.pusatbahasa.or.id; Email: cendekiaoslo@gmail.com

Center of Language and Cultural Studies, Surakarta, Indonesia

Triningsih, Erna Diah. 2018. Peningkatan Kemampuan Memahami Teks Tantangan

Menggunakan Metode Pembelajaran STAD Siswa Kelas IX SMPN 1 Karangploso.

Cendekia (2018), 12(2): 85-98. DOI:10.30957/Cendekia.v12i2.520.

KKM atau termasuk dalam kategori kelompok bawah sebanyak 22 peserta didik atau $73,33 \%$ dan yang termasuk dalam kategori kelompok menengah hanya 8 peserta didik atau 26,67\%. Tidak ada satu orang peserta didik yang termasuk dalam kategori kelompok atas.

Setelah mendapatkan tindakan metode pembelajaran STAD pada siklus 1, kemampuan peserta didik meningkat, yaitu jumlah peserta didik yang nilainya di bawah KKM atau termasuk dalam kategori kelompok bawah sebanyak 10 peserta didik atau $33,33 \%$ dan yang termasuk dalam kategori kelompok menengah sejumlah 15 peserta didik atau 50\%, sedangkan 5 peserta didik atau $16,67 \%$ termasuk dalam kategori kelompok atas yaitu mendapatkan nilai 85 keatas. Pada siklus 2, kemampuan peserta didik semakin meningkat hingga hanya ada dua peserta didik yang nilainya kurang dari KKM atau 6,66\%, sebanyak 17 peserta didik atau 56,67\% mendapatkan rentang nilai 78-84, dan sejumlah 11 peserta didik atau 36,67\% termasuk dalam kategori kelompok atas karena memperoleh nilai 85-100.

Peningkatan keberhasilan pembelajaran juga dapat dibuktikan adanya peningkatan pada aktivitas peserta didik. Berdasarkan data, diketahui rata-rata peningkatan proses pembelajaran memahami teks tantangan siklus 1 ke siklus 2 sebesar $10 \%$ yaitu dari rata-rata siklus 1 sebesar $70,67 \%$ menjadi $80,67 \%$ di siklus 2 . Rincian peningkatan hasil observasi aktivitas peserta didik dari siklus 1 ke siklus 2 berdasar data tabel sebagai berikut, keseriusan peserta didik dalam memahami struktur, ciri bahasa, dan menyimpulkan isi dari teks tantangan sejumlah 22 peserta didik pada siklus 1 dan meningkat menjadi 24 peserta didik pada siklus 2, ketertiban peserta didik dalam mengikuti kegiatan pembelajaran pada siklus 1 sebanyak 20 peserta didik dan meningkat menjadi 23 peserta didik pada siklus 2, kemampuan peserta didik dalam bekerja sama dalam kelompok pada siklus 1 sebanyak 21 peserta didik pada siklus 2 meningkat menjadi 25 peserta didik, keseriusan peserta didik dalam memecahkan masalah, kemandirian peserta didik dalam menjawab kuis sebanyak 24 peserta didik dan meningkat menjadi 26 pada siklus 2, kemampuan dan keaktifan peserta didik memahami materi pada tahap presentasi kelas pada siklus I sebanyak 19 peserta didik dan meningkat menjadi 23 pada siklus 2.

Berdasarkan pengamatan peneliti dan observer selama melakukan penelitian tindakan kelas pada kelas IX SMPN 1 Karangploso, Kabupaten Malang, peneliti menyarankan beberapa hal sebagai berikut.

1. Metode pembelajaran STAD perlu dilaksanakan oleh guru di kelas IX SMPN 1 Karangploso, Kabupaten Malang khususnya dan pada guru di sekolah lain pada umumnya.

2. Guru sebaiknya mampu menerapkan berbagai macam variasi metode pembelajaran untuk menciptakan proses pembelajaran yang menyenangkan sehingga mampu mendorong peserta didik untuk belajar secara maksimal.

\section{DAFTAR RUJUKAN}

Arikunto, Suharsimi. 2008. Penelitian Tindakan Kelas. Jakarta: Bumi Aksara. Hamalik, Oemar. 2008. Kurikulum dan pembelajarannya. Jakarta: Bumi Aksara. 
Handayani, Sri. 2017. Listening Teams: Strategi Pemahaman Isi Teks pada Siswa SMPN 1 Karangploso. Cendekia, (2017), 11(2):129-142.

Isjoni. 2010. Cooperative Learning Evektivitas Pembelajaran Kelompok. Bandung: Alfabeta.

Kumarawati. 2015. Penerapan Metode Pembelajaran Kooperatif Tipe Student Team Achievement Divisions (STAD) untuk Meningkatkan Kemampuan Menulis Teks Laporan Hasil Observasi Siswa Kelas X MIA 1 SMAN 1 Mendoyo. (Online) http://download.portalgaruda.org.

Marcelina. 2012. Efektivitas Metode STAD (Student Team Achievement Divisions) dalam Pembelajaran Menulis Surat Dinas. (Online) http://ejournal.upi.edu.

Mulyanto. 2011. Peningkatan Keterampilan Menulis Karangan dengan Model Pembelajaran Kooperatif Tipe STAD pada Siswa Kelas III SDN Ngargosari Tahun 2011/2012. (Online) http://digilib.uns.ac.id.

Nurhadi. 1987. Membaca Cepat dan Efektif. Bandung: Sinar Baru.

Oka, I Gusti Ngurah. 1983. Pengantar Membaca dan Pengajarannya. Malang: Surabaya: Usaha Nasional.

Paul, Richard dan Linda Elder. 2006. Critical Thinking Concepts and Tools. http://www.criticalthinking.org/files/Concepts Tools.pdf

Schafersman, Steven D. 1991. An Introduction to Critical Thinking. http://facultycenter.ischool.syr.edu/wp-content/uploads/2012/02/CriticalThinking.pdf

Slavin, Robert E. 2010. Cooperatif Learning. Bandung : Nusa Media. Sudaryanto, 2012. Mengatasi Rendahnya Minat Baca di Indonesia. (Online) http://writingsdy.wordpress.com.

Sugiono. 2010. Belajar dan Pembelajaran. Kediri : UNP.

Suprijono, Agus. 2003. Cooperative Learning Teori Dan Aplikasi Paikem. Yogyakarta: Pustaka Pelajar.

Suriati, Ni Luh; Mahsun \& Sudirman. 2018. Kemampuan Menggunakan Majas Perbandingan dalam Produksi Teks Eksemplum Siswa SMP Kelas IX Lombok Utara. Lingua (2018), 15(2):115-130. DOI: 10.30957/lingua.v15i2.481.

Tampubolon, S. 2014. Penelitian Tindakan Kelas sebagai Pengembangan Profesi Pendidik dan Keilmuan. Jakarta: Erlangga. 